\title{
OBRANA HORSKÝCH PŘECHODŮ NA MORAVU A DO UHER NA PŘÍKLADU HRADECKÝCH A JABLUNKOVSKÝCH ŠANCÍ
}

\author{
MARTIN KRŮL
}

\begin{abstract}
Abstrakt: Slezsko často tvořilo předpoli pro válečná taženi proti habsburské monarchii, zejména v 17. a 18. století se stalo svědkem četných válečných kampaní, které ohrožovaly samotnou existenci monarchie. Konflikty druhé poloviny 18. století přinesly ztrátu většiny Slezska a k obraně proti dalši expanzi Pruska na Moravu a do Uher byly budovány polní fortifikace již na hranicích, v př́stupových koridorech horských oblastí. Př́spěvek si klade za cil prezentovat na základě terénního, kartografického a archivního výzkumu dva systémy novověkých fortifikaci - hradecké a jablunkovské šance. Na jejich príkladu lze charakterizovat způsob, jakým byly zabezpečeny hranice monarchie proti vpádi̊m z Pruska a jak se změny ve vojenské strategii a taktice odrazily rovněž na typologii a lokalizaci polních opevnění, hojně využivaných $v$ horském terénu.
\end{abstract}

Kličová slova: fortifikace - polni opevnění-šance - raný novověk-slezské války.

The Defence of Mountain Passes to Moravia and Hungary on the Example of Hradec and Jablunkov Fortifications

Abstract: Silesia often played the part of a no man's land in military campaigns against the Habsburg empire, and especially in the 17th and 18th centuries it witnessed numerous military campaigns that threatened the very existence of the monarchy. Military conflicts in the second half of the 18th century resulted in the loss of the major part of Silesia. In order to stop further expansion of Prussia into Moravia and Hungary, field fortifications were constructed on the borders, in access corridors of mountain areas. This article presents, on the basis of field, cartographic and archive research, two systems of modern-age fortifications, Hradec and Jablunkov fortifications. Their example demonstrates how the monarchy borders were protected against invasions from Poland, and how the changes in military strategy and tactics were reflected in the typology and location of field fortifications, frequently employed in mountain regions.

Key words: fortification - field fortification - early modern age-Silesian wars.

\section{Úvod}

Pevnostní stavitelství představuje fenomén, který se výrazně podepsal na celém období raného novověku. Kvalitativně nový vývoj opevnění, jaký nastal od první poloviny 16. století a v podstatě ovlivňoval vojenskou doktrínu až do první poloviny 19. století, poznamenal tvářnost raně novověké Evropy i zámořských kolonií. Není bez zajímavosti se v této souvislosti zmínit o významu bastionových pevností, jejichž vznik měl natolik zásadním způsobem ovlivnit vývoj vojenství, že je britský historik Geoffrey Parker uvedl jako hlavní agens v modifikovaném konceptu vojenské revoluce (1996; Wohlmuth 2015; Prchal 2015, 25-57). V reakci na rozvoj dělostřelectva, které si od konce 15 . století relativně snadno poradilo se středověkým opevněním měst a hradů, vyvinuli inženýři novou fortifikační doktrínu založenou na nízkých rozlehlých vzájemně se chránících pětiúhelníkových baštách, tzv. bastionech. Tento bastionový opevňovací systém se zanedlouho rozšiŕil z Itálie do celé Evropy a stal se dominantním prvkem, který opět překlopil poměr sil mezi defenzívou a ofenzívou na stranu prvně jmenované. Konsekvence těchto vzájemně se ovlivňujících technologických změn (kromě bastionu rovněž nové užití palebné síly a s tím související technologický a materiálový vývoj) se projevily ve změně taktiky a rovněž v nezbytnosti navýšení lidských zdrojů nejen při budování nových, prostorově větších opevňovacích prvků, ale i při jejich dobývání. Koncentrace vyššího počtu lidí spolu s nutností jejich financování, zásobování, ubytování, ošacení a vyzbrojení zase vytvářela tlak na větší efektivitu při výběru finančních prostředků a $\mathrm{z}$ toho vyplývající centralizaci a byrokratizaci státní administrativy (Parker 1996, 6-81; Prchal 2015, 35-39). Z tohoto úhlu pohledu by se tedy dalo říci, že se bastiony staly důležitým technologickým podnětem, který ve svém důsledku přispěl ke zrodu 
moderní společnosti, i když takto zjednodušená př́íčnnost vycházející z technologického vývoje byla ze strany některých autorů podrobena kritice (Prchal 2015, 38-42).

Problematika pevnostního stavitelství představuje svébytné odvětví, které svým okruhem zájmu stojí na rozhraní několika vědních disciplín. Informace z písemných pramenů je řadí mezi objekty výzkumu historie, ikonografická vyobrazení je pak staví do centra pozornosti dějin umění jako profánní objekty s čistě utilitární funkcí. Největší zájem poutají velké pevnostní stavby dochované ve velkém počtu zejména na území jižní a západní Evropy (Duffy 1979; 1985). Avšak nedílnou součást pevnostního stavitelství tvoří početná polní zemní opevnění, kterým je věnována o poznání menší pozornost. Na rozdíl od velkých permanentních fortifikačních děl spočívala jejich funkce na krátkodobém zajištění vojska během ležení či obléhání, případně na zajištění komunikačních koridorů (průsmyky, mosty, brody) během akutního vojenského ohrožení. Mezi výhody polních opevnění se řadila rychlost výstavby, dostupnost stavebního materiálu (zemina, dřevo) a v neposlední řadě rovněž skutečnost, že výstavba těchto tvarově jednoduchých fortifikací nevyžadovala složité matematické a geometrické výpočty. Soudobé fortifikační manuály uváděly jednoduchý geometrický postup pro výstavbu těchto menších fortifikačních děl „ohne rechnung auffs papier reissen“ (Nottnagel 1659, 174-177). Při zkoumání polních opevnění, u nichž mnohdy nejsou dochována podrobná kartografická zobrazení, sehrává neocenitelnou roli archeologie se svými metodami, které umožňují tyto, ne vždy v písemných či kartografických pramenech zaznamenané, objekty verifikovat, identifikovat a podrobit měření.

\section{Stav výzkumu}

Problematice polních opevnění začíná být věnována $\mathrm{v}$ poslední době stále větší pozornost, která se projevila mimo jiné i pořádáním několika specializovaných konferencí (Josefov 2009, Žacléř 2011, České Budějovice 2016). Ačkoliv zájem o výzkum polních opevnění jako archeologických reliktů spadá již do počátku 90. let (Meduna 1990, 75-86; Matoušek-Hájek-Kubů-Meduna 1990, 29-66; Smrž-Meduna-Brůna-Křivánek 1999, 335-345; Čížek-Slavík 1993, 41-47), teprve výzkumy dochovaných fortifikačních objektů 17. století v konfrontaci s kartografickými a historickými prameny obrátily větší pozornost i na tuto problematiku (Matoušek 2006; 2013, 191-200). Rovněž početné relikty polních opevnění 18. století neunikly pozornosti, zvláště když lze v jejich případě využít vojenská mapování. V tomto ohledu patř́i k nejlépe zdokumentovaným oblasti severozápadních (Nejman 2010, 45-59) a východních Čech (Čížek-Slavík 2010, 37-44). Naproti tomu je opevněním chránícím vstup na Moravu věnována mnohem menší pozornost a v literatuře se prakticky nezmiňují. Z iniciativy Národního památkového ústavu došlo k zaměření reliktů opevnění hradeckých šancí navazujícímu na aktivity z 80 . let 20 . století.

Situace jablunkovských šancí je v tomto ohledu o něco prŕíznivější. Vzhledem k jejich významu pro obranu celého Slezska se zmínky o nich nacházejí prakticky v každém díle zabývajícím se historií Slezska, resp. těšínského Slezska. Dochované relikty šancí na české straně hranice byly zaměřeny, avšak nebyl zde proveden archeologický výzkum (Bednár a kol. 2011, 46-47). Na dnešní slovenské straně hranice proběhly drobné sondážní výzkumy již v 70. a 90. letech 20. století (Šedo 1977, 264-265; Ďurišová 1995, 36-37). Největší záchranný archeologický výzkum byl proveden na opevnění Malá šance a liniovém valu s redany a redutami v Čierne pri Čadci, avšak bohužel až v situaci před plánovanou výstavbou mezinárodní dálnice procházející přes fortifikační prvky, čímž zřejmě dojde $\mathrm{k}$ jejich devastaci a ztrátě dalších informací (Vojteček 2016, 195-209).

Prezentovaný příspěvek se pokusí nastínit, jakým způsobem byly chráněny horské přechody na Moravu a do Uher prred útoky ze Slezska. Na př́íkladu dvou relativně dobře dochovaných systémů polních opevnění nazývaných hradecké a jablunkovské šance lze vysledovat změny v obraně horských území, které byly reakcí na taktický a strategický vývoj a odrazily se v typologii a lokalizaci opevnění. Jablunkovské šance jako systém polních opevnění budovaný na ochranu jižní slezské hranice před útoky z Uher se začaly konstituovat již v první polovině 16. století v reakci na expanzi osmanské říše do prostoru střední Evropy. Svůj význam, ačkoliv 
již menší, si opevnění podržela rovněž v 18. století, kdy byla zaměřena na obranu před novým protivníkem habsburské monarchie Pruským královstvím. Proti stejnému nepříteli začaly být fortifikovány ve druhé polovině 18 . století rovněž př́istupové koridory v jižní části rakouského Slezska na Moravu. Z opevnění v těchto místech se mezi nejzachovalejší řadí hradecké šance budované v okolí Hradce nad Moravicí.

\section{Historické souvislosti}

Čtyři válečné konflikty druhé poloviny 18. století (1. a 2. slezská, sedmiletá válka a válka o bavorské dědictví) přinesly habsburské monarchii citelnou územní ztrátu velké části Slezska ve prospěch Pruského království. V rámci monarchie zůstala pouze malá část nazývaná rakouské či české Slezsko. Výrazné přiblížení nové hranice s Pruskem tak vyvolalo nutnost zabezpečit přístupové cesty ze Slezska na Moravu a do Uher.

Nečekaný vpád pruských vojsk v zimě roku 1740, během něhož tato snadno obsadila celé Slezsko, rozhodl fakticky o dalším osudu území. Rakouská armáda se několikrát pokusila tento stav zvrátit, avšak bezúspěšně. Snadné přechody pruských vojsk do Čech a na Moravu přes hraniční pohoří ukázaly nutnost výstavby opevnění již na hranicích země. Na Moravě představovalo hlavní bod obrany město-pevnost Olomouc. Jeho důležitost a strategický význam prokázaly předchozí konflikty, zvláště obsazení města Švédy v době třicetileté války, kdy se Olomouc stala hlavním opěrným bodem švédské moci na Moravě až do roku 1650 (Dudík 1879). Olomouci byla po těchto zkušenostech věnována pozornost a došlo $\mathrm{k}$ přestavbě opevnění, které se osvědčilo během obležení pruskými vojsky za sedmileté války v roce 1758 (Kuch-Breburda-Kupka 2003, 63-135). Naproti tomu zastaralá opevnění městských center v rakouském Slezsku (Opava, Krnov) již nevyhovovala z taktického ani strategického hlediska novému vývoji vojenství, o čemž svědčila jejich téměř pravidelná obsazování nepřátelským vojskem (Uhlíř 2012, 363-398; Kolář 2013, 101-103). Ze strategického hlediska bylo nutné zajistit př́istupové koridory od severu po celé délce hranice souvislou řadou polních opevnění, která by zabránila, případně zpomalila postup nepř́itele již na vstupu do země.

\section{Hradecké šance}

Mezi nejlépe zachovaná opevnění se řadí systém hradeckých šancí. Jednalo se o soustavu polních opevnění budovaných na katastru dnešního města Hradce nad Moravicí (místní části Benkovice a Jakubčovice) a obce Vršovice, která vytvářela účinnou zábranu před vpádem nepřátelských vojsk ze severozápadního a severního směru. Zajišt'ovala ochranu přístupových cest směrem do hloubi Moravy a bránila vytvoření nástupního prostoru k obléhání pevnosti Olomouc. Všechna výše uvedená opevnění jsou situována na pravém břehu řeky Moravice. Opava jako nejbližší a největší město v okolí byla během čtyř válečných konfliktů druhé poloviny 18. století pravidelně obsazována pruskými vojsky a rakouské oddíly se musely stáhnout hlouběji do vnitrozemí, za řeku Moravici. Po překonání řeky pak postupujícím jednotkám již v cestě na hlavní pevnost Olomouc nic nestálo.

Prvotní fortifikační aktivity, většinou však ad hoc reagující na vojenské ohrožení, můžeme vysledovat již po skončení 2 . slezské války v roce 1745 , kdy je doložena výstavba reduty a opevnění kolem zámku v Hradci nad Moravicí (ZAO, KrÚ). K dalšímu opevňování přístupových cest na Moravu přistoupily rakouské úřady po skončení sedmileté války a v době války o bavorské dědictví v letech 1778-1779. Ta měla poziční charakter a během ní obě strany hojně využívaly polních opevnění pro zesílení svých pozic již na vstupu do země.

\section{Kartografické vyobrazení na vojenských mapováních}

Pro toto období již můžeme využit kartografické prameny, a to I. vojenské mapování. Území rakouského Slezska bylo zmapováno nejdříve, v letech 1763 a 1764. Pro velké nedostatky 
došlo v roce 1780 k novému mapování většiny sekcí, deset (patrně těšínského Slezska) bylo korigováno a zbývajících třicet sekcí bylo pořízeno nově (Korbelářová-Žáček 2005, 3-4). Znázorněné fortifikace na mapových listech I. vojenského mapování ukazují tedy stav po sedmileté válce a válce o bavorské dědictví.

Účel obranných zařízení je zřejmý z textových př́iloh k mapování Slezska. U údajů o Hradci je v poznámce uvedeno, že se zde nachází výhodné postavení pro jeden batalión a 200 mužů lehké jízdy, které by uzavřely dobrou cestu z Opavy na Moravu (Korbelářová-Žáček 2005, 35). Mapová sekce 23 zaznamenává čtyři objekty, v Benkovicích, Hradci a Brance. Dva z nich se nacházejí v prostoru vrchu Hanuše, severozápadně od Hradce. Z typologického hlediska byly tvořeny otevřenými zemními prvky s valem a prríkopem. Fortifikace v poloze Před Hanuší tvořila redan s plochým čelem, zatímco na kopci Hanuše se nacházela reduta s otevřenou týlní stranou (podle Medunovy typologie by bylo možno hovořit o redanu s prodlouženým čelem a pravoúhlými bočními flanky [1991, 77]). Třetím objektem pak byla uzavřená reduta na jižní straně ostrožny hradeckého zámku. Posledním objektem na mapové sekci je opevnění ve tvaru lunety na katastru obce Branka. Je situováno na severozápadním okraji Braneckého kopce, který tvoří začátek terénních útvarů vytvářejících východní hradbu údolí řeky Moravice. Její poloha umožňovala kontrolovat př́stup ze severního směru do prostoru údolí (obr. 1).

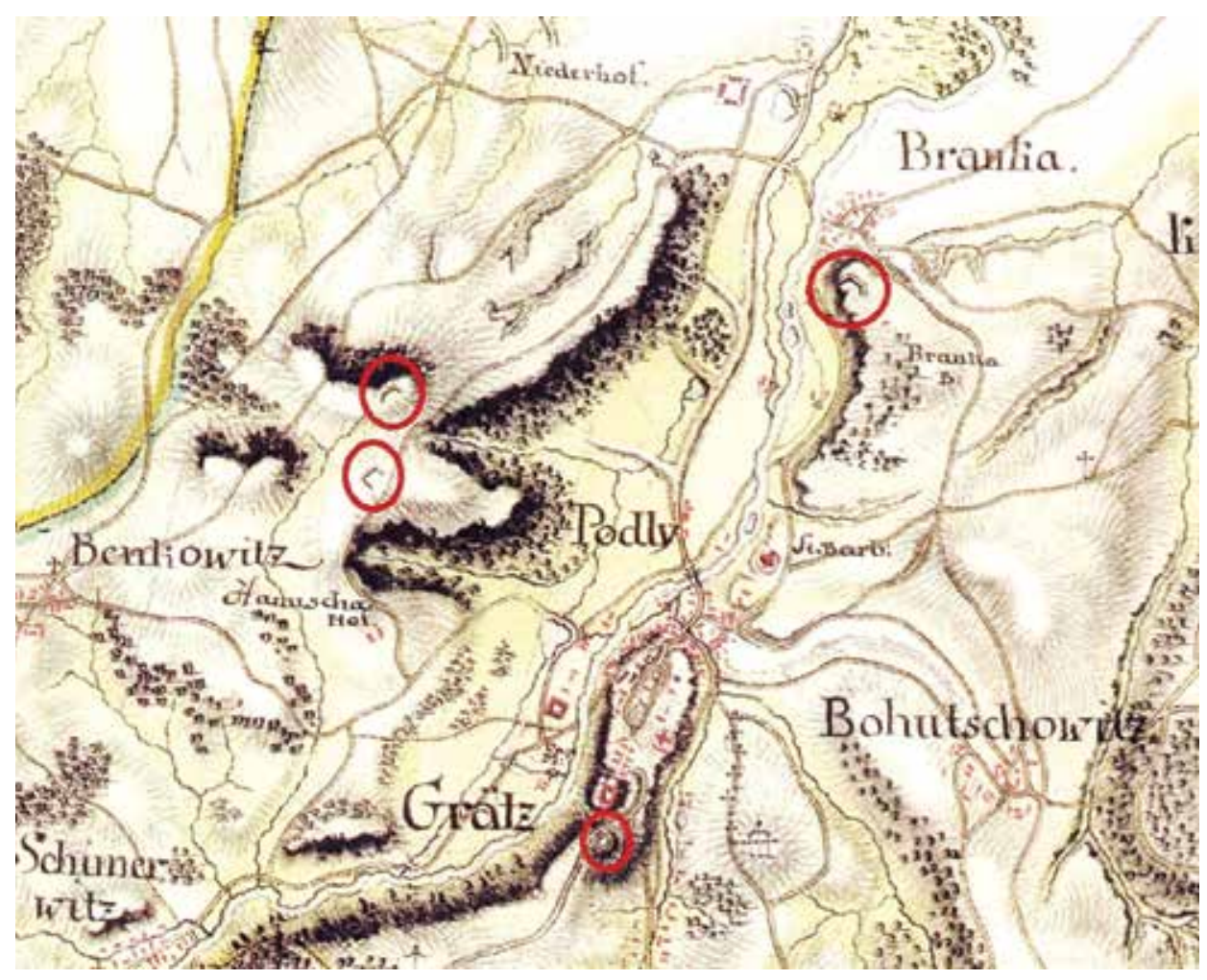

Obr. 1. Výřez mapového listu I. vojenského mapování se znázorněním fortifikací v okolí Hradce nad Moravicí. (C) $1^{\text {st }}\left(2^{\text {nd }}\right)$ Military Survey, Section No. xy, Austrian State; Archive / Military Archive, Vienna; (C) Laboratoř geoinformatiky Univerzita J. E. Purkyně, http://www.geolab.cz; (C) Ministerstvo životního prostředí ČR, http://www.env.cz.

Abb. 1. Ausschnitt aus einem Kartenblatt der I. militärischen Kartierung mit eingezeichneten Befestigungen in der Umgebung von Grätz (Hradec nad Moravicí). (C) $1^{\text {st }}\left(2^{\text {nd }}\right)$ Military Survey, Section No. xy, Austrian State Archive/Military Archive, Vienna; (C) Labor der Geoinformatik der Universität J. E. Purkyně, http://www.geolab.cz; (C) Umweltministerium der Tschechischen Republik, http://www.env.cz. 
Největší počet opevnění vykazují mapové sekce II. vojenského mapování pro Moravu a Slezsko vyhotovené v letech 1836-1840 a mapy stabilního katastru, z něhož toto mapování vycházelo. Zabezpečení této části hranice s Pruskem bylo spjato se jménem generála Ernsta Gideona Laudona (1717-1790), který vydal 11. května 1790 rozkaz založit všude podél ní šance a zř́idit záseky (Tschink 1791, 265). Z roku 1790 se dochoval soupis plateb a seznam civilních pracovníků z obcí hradeckého panství, kteří se od května do července podíleli na výstavbě „Feldverschanzungen zu Grätz“ (ZAO, Vs Hradec). Podle názvu opevnění na mapách II. vojenského mapování (Grätz. Schanze) můžeme tyto fortifikační aktivity v Hradci vztáhnout na výstavbu objektu na vrchu Kalvárie. Do stejné doby pak lze datovat výstavbu soustavy opevnění v prostoru obce Jakubčovice, označené na mapách II. vojenského mapování souhrnným názvem jakubčovické šance (Jakubsch. Schanze; obr. 2).

Během svého následujícího pobytu, kdy si zrrídil 21. června svůj hlavní stan v Novém Jičíně, vizitoval generál Laudon hraniční postavení. Zároveň vydal rozkaz opevnit zámek v Hradci a zabezpečit Opavu a Krnov záseky a šancemi. Při pobytu na hradeckém zámku u knížete Lichnovského 26. června však onemocněl a následujícího dne odjel do Nového Jičína, kde na následky nemoci zemřel (Tschink 1791, 266-267).

\section{Dochovaná opevnění hradeckých šancí}

Z fortifikací znázorněných na mapových listech I. vojenského mapování se do současnosti dochovaly dva relikty opevnění v Benkovicích. V poloze Před Hanuší se jedná o relikt redanu, který byl však druhotně poškozen. Je orientován severním směrem a představuje nejdále na severozápad umístěný prvek soustavy hradeckých šancí. Souvisí s redutou na Hanuši, pro kterou vytvářel předsunuté postavení. Ve vnitřním prostoru jsou patrny blíže neidentifikovatelné úpravy do kamenného podloží (cisterna?; obr. 3).

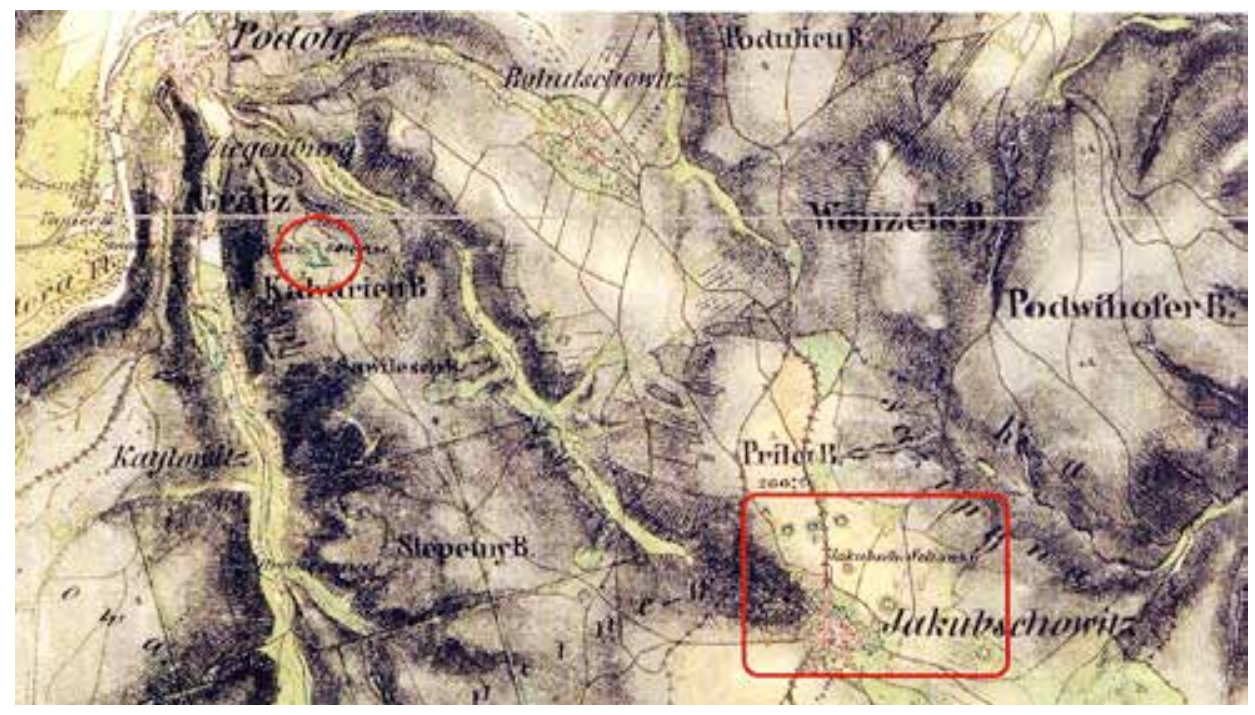

Obr. 2. Nové fortifikace znázorněné na mapovém listu II. vojenského mapování v Hradci nad Moravicí a Jakubčovicích. (C) $1^{\text {st }}\left(2^{\text {nd }}\right)$ Military Survey, Section No. xy, Austrian State Archive/Military Archive, Vienna; (C) Laboratoř geoinformatiky Univerzita J. E. Purkyně, http://www.geolab.cz; @ Ministerstvo životního prostředí ČR, http://www.env.cz.

Abb. 2. Neue, auf einem Kartenblatt der II. militärischen Kartierung eingezeichnete Befestigungen in Grätz (Hradec nad Moravicí) und Jakubčovice. (C) $1^{\text {st }}\left(2^{\text {nd }}\right)$ Military Survey, Section No. xy, Austrian State Archive/Military Archive, Vienna; 드 Labor der Geoinformatik der Universität J. E. Purkyně, http://www.geolab.cz; (C) Umweltministerium der Tschechischen Republik, http://www.env.cz. 


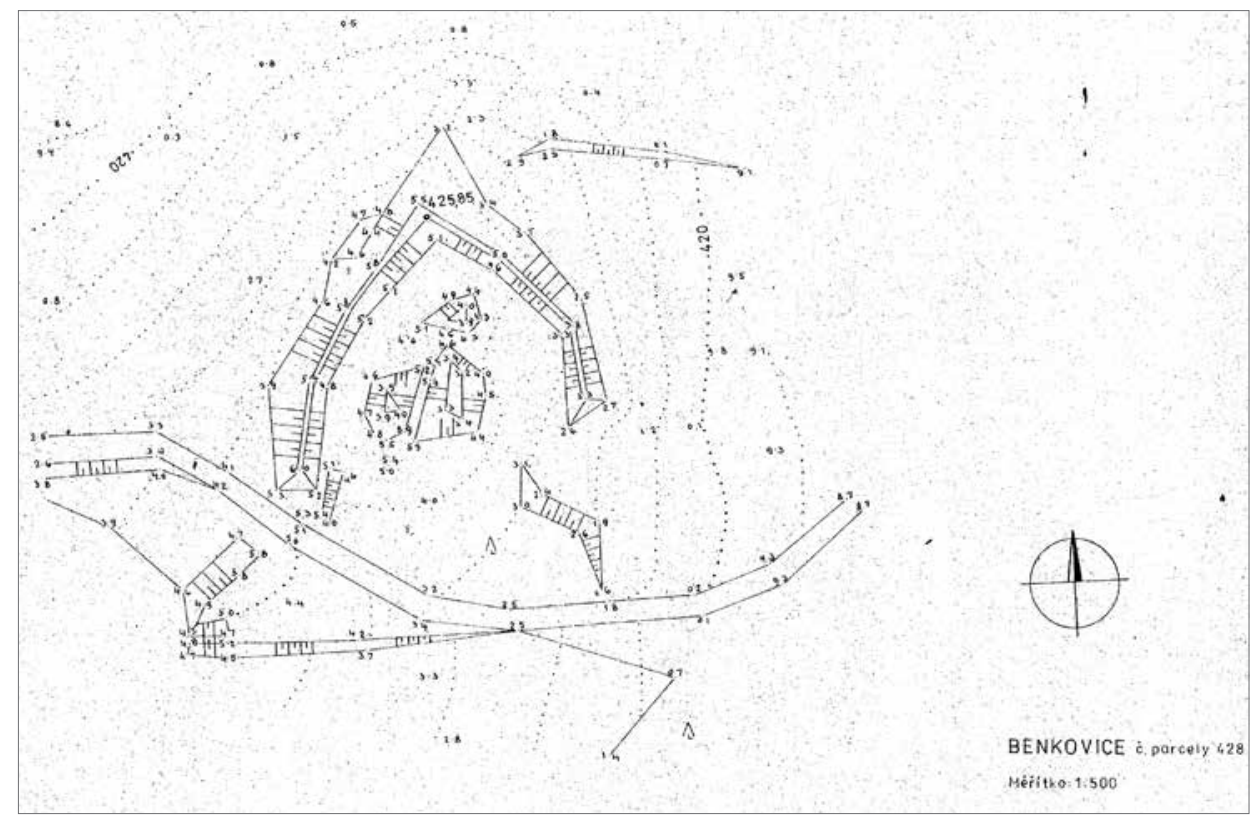

Obr. 3. Opevnění v poloze Před Hanuší v Benkovicích, které tvořilo nejdále severozápadním směrem vysunuté postavení hradeckých šancí. Podle Lissek-Stoklasa 1988. Archiv NPÚ.

Abb. 3. Befestigung in der Lage Před Hanuší (vor dem Berghügel Hanuše) in Benkovice, welche die am weitesten in nordwestlicher Richtung vorgezogene Stellung der Grätzer Schanzen bildete. Nach Lissek-Stoklasa 1988. Archiv des Nationalen Denkmalinstituts.

Na nedalekém vrchu Hanuše se nachází dobře zachovaná reduta s otevřenou týlní částí respektující zobrazení na mapovém listě I. vojenského mapování. Opevnění je orientováno západním směrem. Týlní část reduty není chráněna zemním valem, ale pouze př́íkopem. Spolu s opevněním Před Hanuší kontrolovala př́stupové cesty ze severozápadního směru (obr. 4).

Obě dochovaná opevnění respektují podobu, jaká je zaznačena na mapách I. vojenského mapování. Podle doby tvorby mapových podkladů, pokud byly mapové sekce rektifikovány v roce 1780 , lze určit rámcovou dobu výstavby v rozmezí od sedmileté války (1756-1763) až do konce války o bavorské dědictví (1778-1779). S ohledem na taktické manévry obou armád během války o bavorské dědictví a zajištování postavení polními dělostřeleckými fortifikačními prvky lze s největší pravděpodobností klást dobu vzniku opevnění na vrchu Hanuše právě do souvislosti s válečnými aktivitami tohoto konfliktu, a to bud' již během něj, nebo nedlouho po jeho skončení.

Větší množství reliktů opevnění se dochovalo z objektů zakreslených v mapách II. vojenského mapování. Nejmohutnější opevnění vzniklo v Hradci nad Moravicí na vrchu Kalvárie. Jednalo se o dělostřeleckou polní fortifikaci nepravidelného polygonálního půdorysu se dvěma neregulérními bastiony na severní straně, která byla na západní straně porušena výstavbou křížové cesty. Opevnění tvořené zemním valem a př́íkopem je orientováno severoseverovýchodním směrem. Tato strategicky situovaná poloha umožňovala kontrolovat př́ístupovou cestu do údolí Moravice ze severu (obr. 5).

Podobně mohutné dělostřelecké postavení bylo vybudováno na katastru nedaleké obce Vršovice na vrchu Šance situované na jihovýchod od Hradce, které chránilo př́stup ze západního směru a komunikaci z Hradce na Jakubčovice. Opět se jednalo o dělostřeleckou fortifikaci polygonálního tvaru tvořenou zemním valem se stopami kamení a suchým prŕikopem s nízkým valem a nájezdovými rampami uvnitř (obr. 6). 


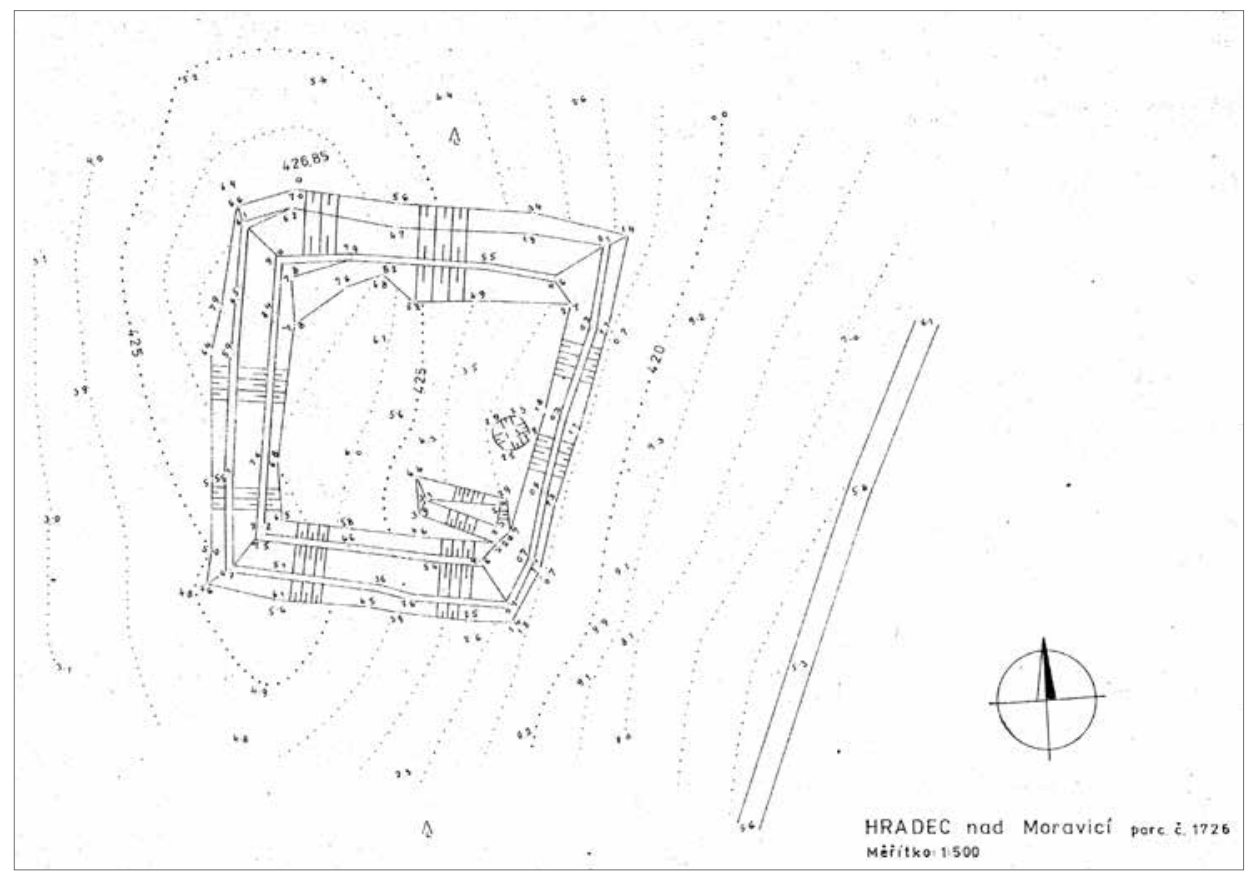

Obr. 4. Dělostřelecká reduta v Benkovicích na vrchu Hanuše. Podle Lissek-Stoklasa 1988. Archiv NPÚ.

Abb. 4. Artillerieredoute in Benkovice auf dem Berghügel Hanuše. Nach Lissek-Stoklasa 1988. Archiv des Nationalen Denkmalinstituts.

Na katastru obce Jakubčovice bylo vybudováno ve třech liniích na výrazných terénních vlnách několik redut, redan, uzavřená luneta a nepravidelné polygonální opevnění. Do dnešních dnů se dochovaly relikty čtyř fortifikací, z nichž dvě byly navíc poškozeny současnou hospodářskou činností.

V Jakubčovicích - Šanci (Pod Př́letem) se nachází dobře dochované dělostřelecké polní opevnění v podobě nepravidelné čtvercové reduty tvořené zemním valem a př́ikopem s nájezdovými rampami ve třech nárožích. Dobře patrný je i nízký val chránící vstup do reduty. Nedaleko od ní je dochován relikt nároží severní části destruované reduty (obr. 7).

Polní opevnění v Jakubčovicích - Zádvoří tvoří destruovaná dělostřelecká fortifikace, z níž se dochovala pouze východní část. Podle vyobrazení z mapy II. vojenského mapování se původně jednalo o uzavřenou, jižně orientovanou lunetu s nájezdovou rampou ve špici.

Nejmohutnější polní opevnění v Jakubčovicích se nachází na vrchu Kamenný šanc. Dělostřelecká fortifikace polygonálního tvaru je tvořena zemním valem a příkopem. Ve valu i v příkopu jsou patrny zbytky kamení nebo kamenných vrstev. Na některých místech (východní a jihovýchodní strana) je př́íkop dvojitý. Opevnění je však na východní straně poškozeno těžbou kamenného lomu, což brání přesnějšímu určení složité tvarové dispozice (obr. 8).

Na rozdíl od jablunkovských šancí, které přestaly plnit svou vojenskou funkci v první polovině 19. století, význam hradeckých šancí na obranu před Pruskem zůstal zachován i nadále. Svědčí o tom podrobný popis jednotlivých postavení i s údaji o zajištění přístupových cest na Moravu spolu s předpokládanými počty jednotek a děl vyhotovený 8 . června 1830 kapitánem Rousseauem. Bohužel se k popisu nedochovalo kartografické zobrazení (OESTA-KA, Karten und Plansammlung). 


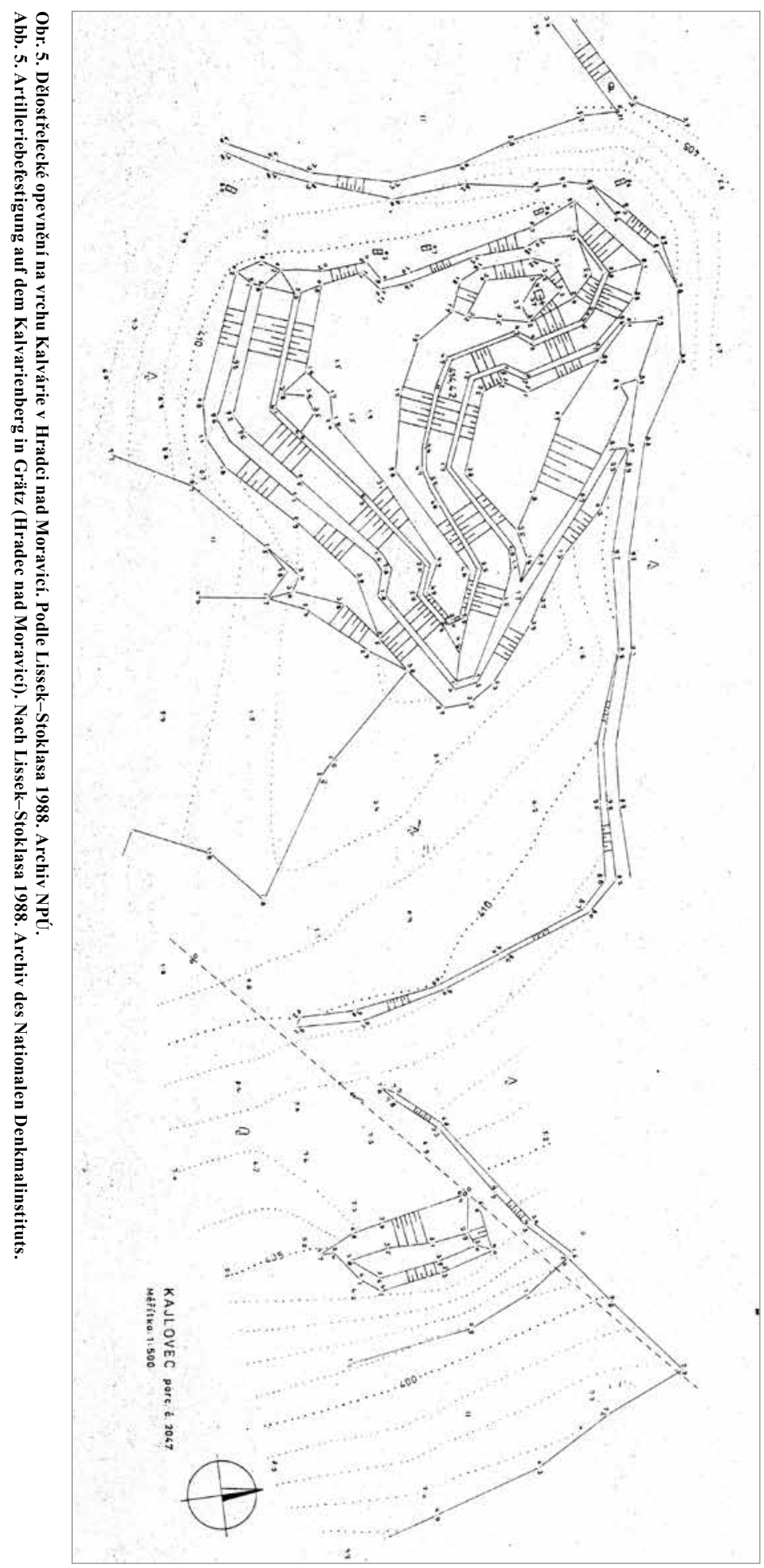




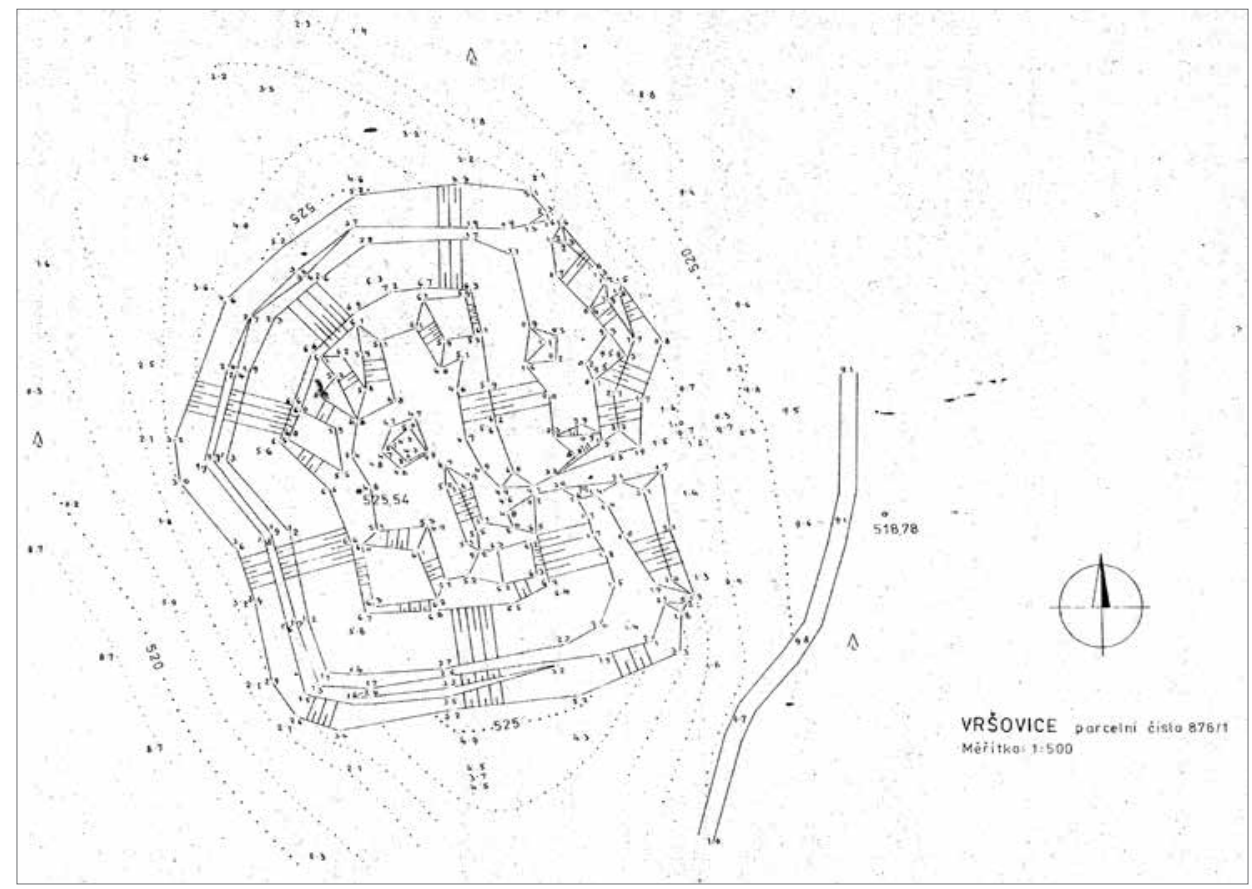

Obr. 6. Polygonální dělostřelecká fortifikace ve Vršovicích. Podle Lissek-Stoklasa 1988. Archiv NPÚ. Abb. 6. Polygonale Artilleriebefestigung in Vršovice. Nach Lissek-Stoklasa 1988. Archiv des Nationalen Denkmalinstituts.

\section{Jablunkovské šance}

Na opačném, jihovýchodním konci území rakouského Slezska, na hranicích s Uhrami a Polskem, se nacházel další systém opevnění, nazývaný jablunkovské šance. Opevnění zde měla prvotně chránit území Slezska před vpády z Uher, avšak od druhé poloviny 18 . století byl jejich účel zaměřen na ochranu vstupu do Uher před útokem z Pruska, tedy ze zcela opačného směru. Nejvýhodnější místo k překročení horského pásma Karpat (Moravskoslezské, Slezské a Slovenské Beskydy) představoval Jablunkovský průsmyk a právě pro tuto strategickou vlastnost se stal předmětem opevňování již od první poloviny 16 . století, kdy po prohrané bitvě u Moháče v roce 1526 hrozilo nebezpečí vpádu vojenských oddílů osmanské říše na území Slezska. V rámci vývoje jablunkovských šancí lze vymezit dvě hlavní období. Starší doba existence fortifikací je ve znamení obrany před útoky z neklidných Uher, tedy z jižního či jihovýchodního směru. Tato etapa trvala zhruba od druhé poloviny 16 . do první třetiny 18. století (Klawitter 1941, 33-34, 69-71, 94-98, 128-132).

Druhé období charakterizuje diametrálně odlišná orientace obrany, která se, díky výše uvedeným geopolitickým událostem, musela změnit a chránit zemi před útokem ze strany Pruska čili ze severozápadního směru (Krůl 2013, 64-71).

\section{Jablunkovské šance do slezských válek}

Jednotlivé prvky jablunkovských šancí vznikaly vždy jako reakce na vzrůst nebezpečí ohrožení útoky z Uher. První pramenné zmínky o zabezpečení hranice pocházejí již z let 1529 , 1541, 1543 a 1566, avšak není zcela jisté, zda k realizaci skutečně došlo. V případě vyslyšení těchto protitureckých nařízení lze předpokládat, že se jednalo o zabezpečení hranice formou 


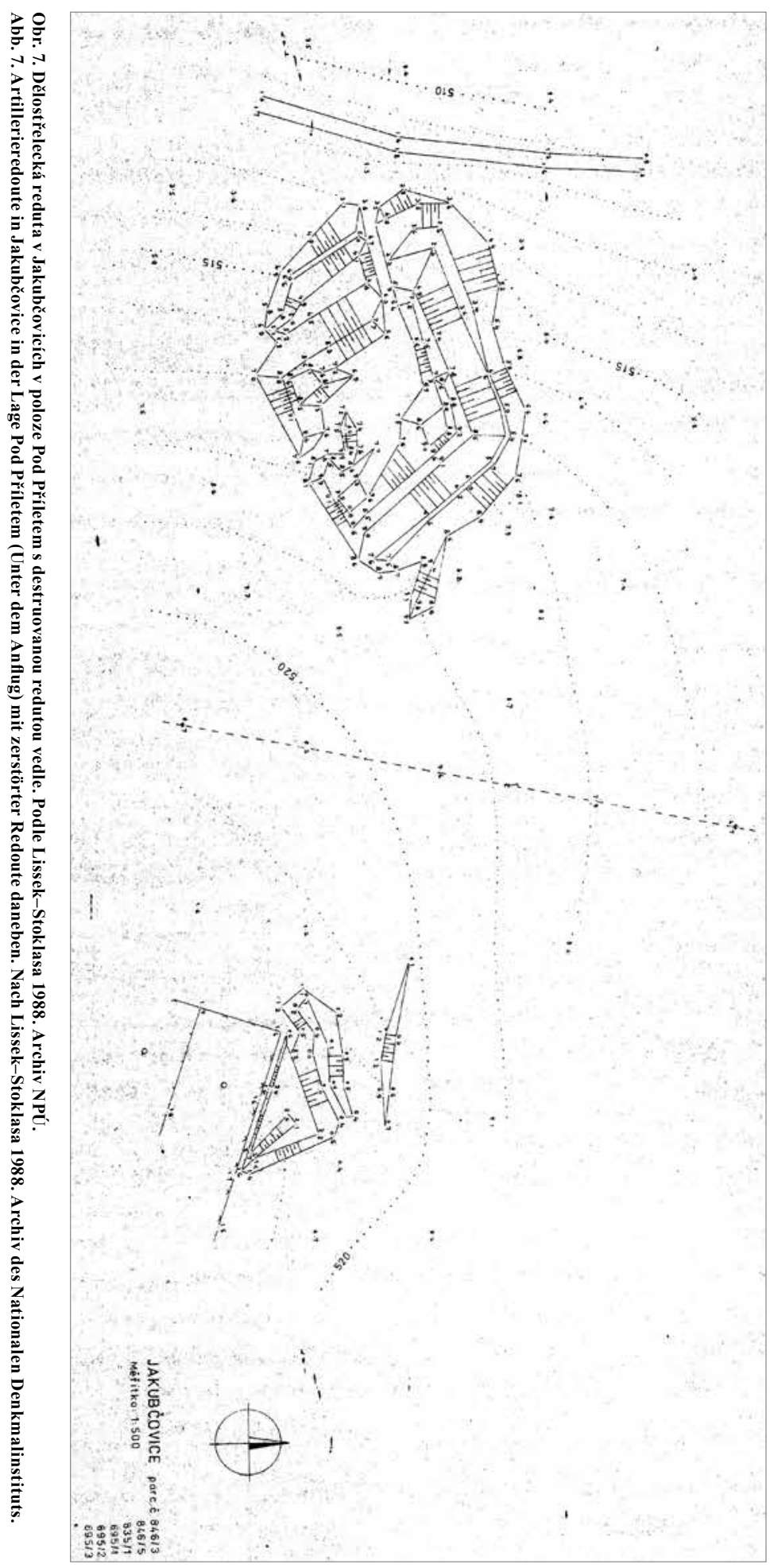




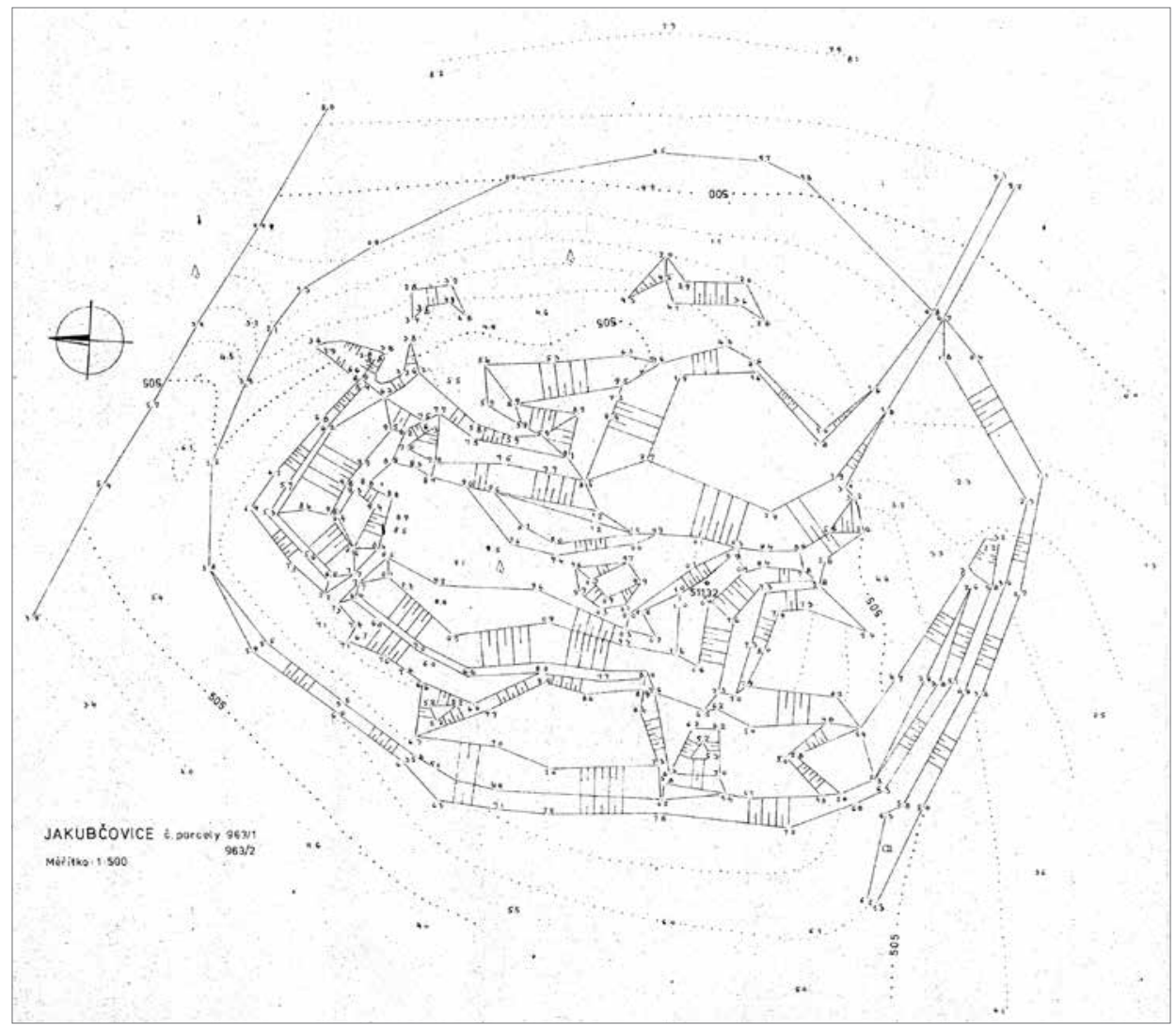

Obr. 8. Největší fortifikace z jakubčovických opevnění v poloze Kamenný šanc. Podle Lissek-Stoklasa 1988. Archiv NPÚ. Abb. 8. Die größte Befestigung der Jakubschowitzer Befestigungen in der Lage Kamenný šanc (Steinschanze). Nach LissekStoklasa 1988. Archiv des Nationalen Denkmalinstituts.

záseků čili o zneprůchodnění hraničního pohoří, tehdy ještě minimálně dotčeného hospodářskou činností, a zemské cesty pomocí pásů setnutých stromů (Diller 1955, 32-34). První doložené opevnění vzniklo v roce 1578 ,na kopci za městečkem Jablunkovem“ (Krůl 2013, 61), lze jej nejpravděpodobněji ztotožnit s fortifikací lokalizovanou v nejvyšším bodě průsmyku, v katastru Svrčinovce (dnes Slovensko). Pro to by svědčilo i její pojmenování na nejstarších mapách hraničního prostoru, kde byla již označena jako Stará šance (Krůl-Nováková 2005, 41).

Období, ve kterém došlo k rozšíření počtu fortifikací, představovala třicetiletá válka (16181648). V této době docházelo rovněž k dokončování a stabilizaci osidlování horských poloh Beskyd, které sehrávalo svou roli při vzniku a lokalizaci opevnění. Jejich umístění v prostoru souviselo s postupující kolonizací z uherské (slovenské) strany, mnohdy spojenou se šířením uherských povstaleckých aktivit. Hospodářská činnost směřující na jižní svahy Beskyd měla zároveň za následek odlesňování a vznik nových stezek, jehož důsledkem byla snazší průchodnost území, a tím i snižování obranyschopnosti celé hraniční oblasti. V období třicetileté války, z něhož již pochází podrobnější písemné zprávy o budování opevnění, byla vytvořena základní struktura jablunkovských šancí, které již bránily celý úsek slezské hranice od moravské po polskou část (Bednár 2008, 12-19; Krůl 2010, 12-15). 
Starší období obrany Jablunkovského průsmyku představuje užití polních šancí nejčastěji ve tvaru čtvercové reduty či hvězdicovité šance. Výjimku tvořil centrální bod, Velká (Jablunkovská) šance ve formě bastionové šance postupně doplňované o další fortifikační prvky - rohovou hradbu a dvojité kleště, obehnané vnější kleštovitou frontou. Tři větší opevnění se složitější typologií - Velká šance (šance s bastiony), Malá šance (hvězdicovitá šance) a Stará šance (reduta s půlbastiony) - tvořila hlavní body obrany následně doplněné o Volskou šanci ve tvaru větší reduty na polských hranicích. Mezi těmito fortifikacemi byla vybudována soustava menších redut sloužících jako komunikační nebo předsunutá postavení opevnění (Krůl-Nováková 2005, 41, 43, 46; obr. 9).

\section{„Pruské“" období systému opevnění}

Nastavení systému opevnění proti útokům z jihu přetrvávalo pod dojmem několik desetiletí trvajícího ohrožení z tohoto směru až do 40 . let 18. století. Rychlé obsazení většiny Slezska během 1. slezské války a výrazné přiblížení pruské hranice vyvolaly naléhavou potřebu inovovat zdejší fortifikace a doplnit je o nová postavení, která by lépe odpovídala soudobým vojenským trendům.

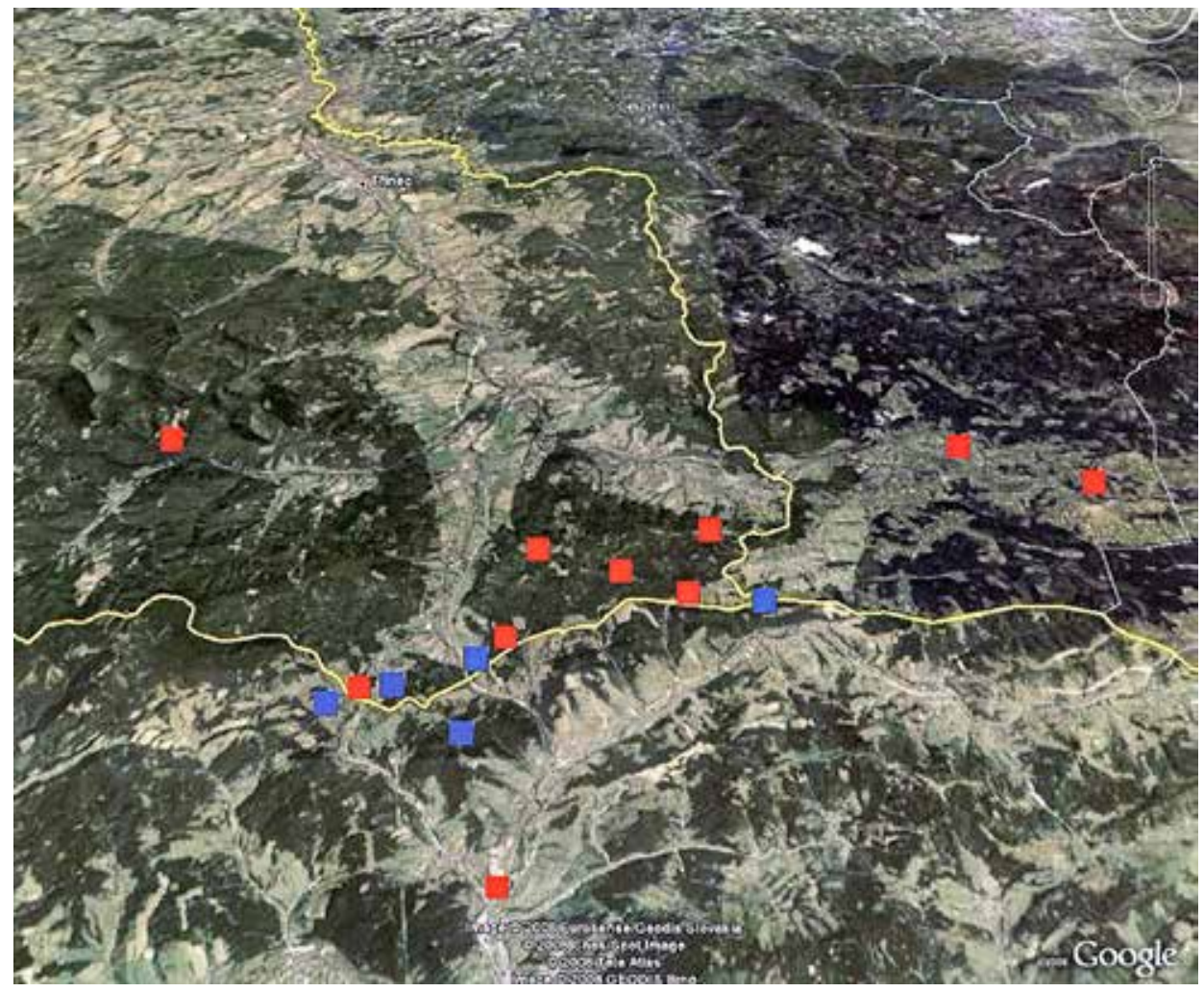

Obr. 9. Vyznačení všech v pramenech doložených fortifikací, které byly vybudovány v prostoru slezsko-uherské hranice do poloviny 18. století na ochranu před útoky z jihovýchodního směru. Červená - nedochovaná fortifikace, modrá - dochovaná fortifikace. Zdroj podkladové mapy Google Earth.

Abb. 9. Kennzeichnung aller in den Quellen belegter Befestigungen, die im schlesisch-ungarischen Grenzraum bis zur Mitte des 18. Jahrhunderts zum Schutz vor Angriffen aus südöstlicher Richtung erbaut worden sind. Rot - nicht erhalten gebliebene Befestigung, blau - erhalten gebliebene Befestigung. Quelle Basiskarten Google Earth. 


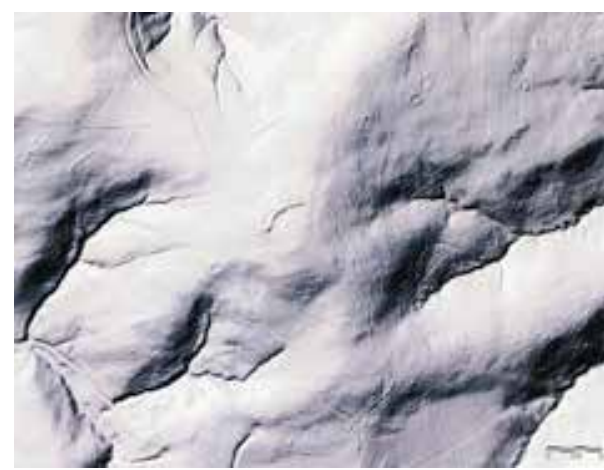

Obr. 10. Vyobrazení redanu v Bukovci - Dílku na výřezu mapy zpracované metodou LIDAR. Zdroj podkladové mapy www.geoportal.gov.pl.

Abb. 10. Darstellung einer Redan in Bukovec - Dílek in einem mit der LIDAR-Methode bearbeiteten Kartenausschnitt. Quelle Basiskarten www.geoportal.gov.pl.

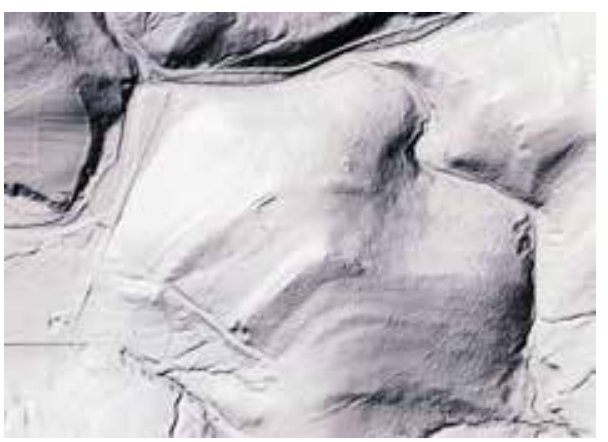

Obr. 12. Redan v Bukovci - Hrádku, který nefiguruje v kartografických pramenech, nalezený díky mapám vytvořeným metodou LIDAR. Zdroj podkladové mapy www. geoportal.gov.pl.

Abb. 12. Redan in Bukovec - Hrádek, die in den kartographischen Quellen nicht figuriert und anhand von mit der LIDAR-Methode erstellten Karten entdeckt wurde. Quelle Basiskarten mapa www.geoportal.gov.pl.

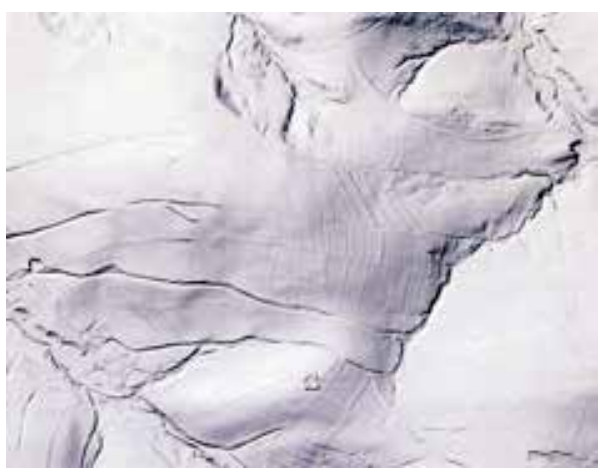

Obr. 11. Pohled na dělostřeleckou redutu v Bukovci - Suši a tři terénu přizpůsobené redany na protilehlém kopci Kempa na mapě vytvořené metodou LIDAR. Zdroj podkladové mapy www.geoportal.gov.pl.

Abb. 11. Blick auf die Artillerieredoute in Bukovec - Suš und auf drei dem Gelände angepassten Redans auf dem gegenüberliegenden Hügel Kempa auf einer mit der LIDAR-Methode erstellten Karte. Quelle Basiskarten www. geoportal.gov.pl.

Podobně jako u hradeckých šancí je i část těchto nových opevnění znázorněna teprve na mapách II. vojenského mapování. Jednalo se o redan na vrcholu kopce Dílek (fortifikace zakreslena na vojenském mapování Uher) a tři redany na nedalekém rozlehlém vrcholu Kempa. Kromě tohoto fortifikačního prvku se zde nacházely rovněž dělostřelecké reduty $\mathrm{s}$ nájezdovými rampami $\mathrm{v}$ rozích, a to $\mathrm{v} \mathrm{Bu}-$ kovci - Suši (o rozměrech $30 \times 30 \mathrm{~m}$ ) a menší reduta $v$ Megoňkách. Vedle zmíněných opevnění, která jsou zachycena kartograficky, byl nalezen další redan v Bukovci - Hrádku, tvarově analogický s redanem na nedalekém vrcholu Kempa a velikostně s redanem na Dílku (obr. 10, 11, 12).

Z typologického hlediska se tedy jednalo o kvalitativně rozdílný prvek vzhledem $\mathrm{k}$ dosavadnímu opevnění. Tato dělostřelecká postavení ve formě redanu a uzavřené reduty se odlišovala od stávajících fortifikací rovněž svou lokalizací na vrcholcích výrazných rozlehlých kopců, z nichž bylo možné ovládat přístupové cesty do Uher a rovněž cestu do Haliče, která nově připadla habsburské monarchii. Co se týče doby výstavby, můžeme ji rovněž v tomto př́ípadě klást do doby války o bavorské dědictví a zajištování hranice s Pruskem v letech 1789-1790.

Fortifikační aktivity z konce 80 . let 18 . století jsou i zde spjaty s rakouským vojevůdcem Laudonem. Rakouská armáda byla zaneprázdněna válkou s Tureckem, která probíhala v letech 1787-1792. Pro zajištění severní hranice monarchie proti nepřátelskému Prusku pak měl sloužit řetěz polních opevnění budovaný od hranic s Haličí a Uhrami až na hranice Čech, kde již podobný systém opevnění existoval (Kaufmann 2007, 254-255). Typologicky podobné polní prvky se nacházely rovněž u sídelního města Těšína. Dnes již nedochované objekty byly vybudovány na terénní vlně západně od města mezi obcemi Mistřovice a Chotěbuz a jejich úkolem 


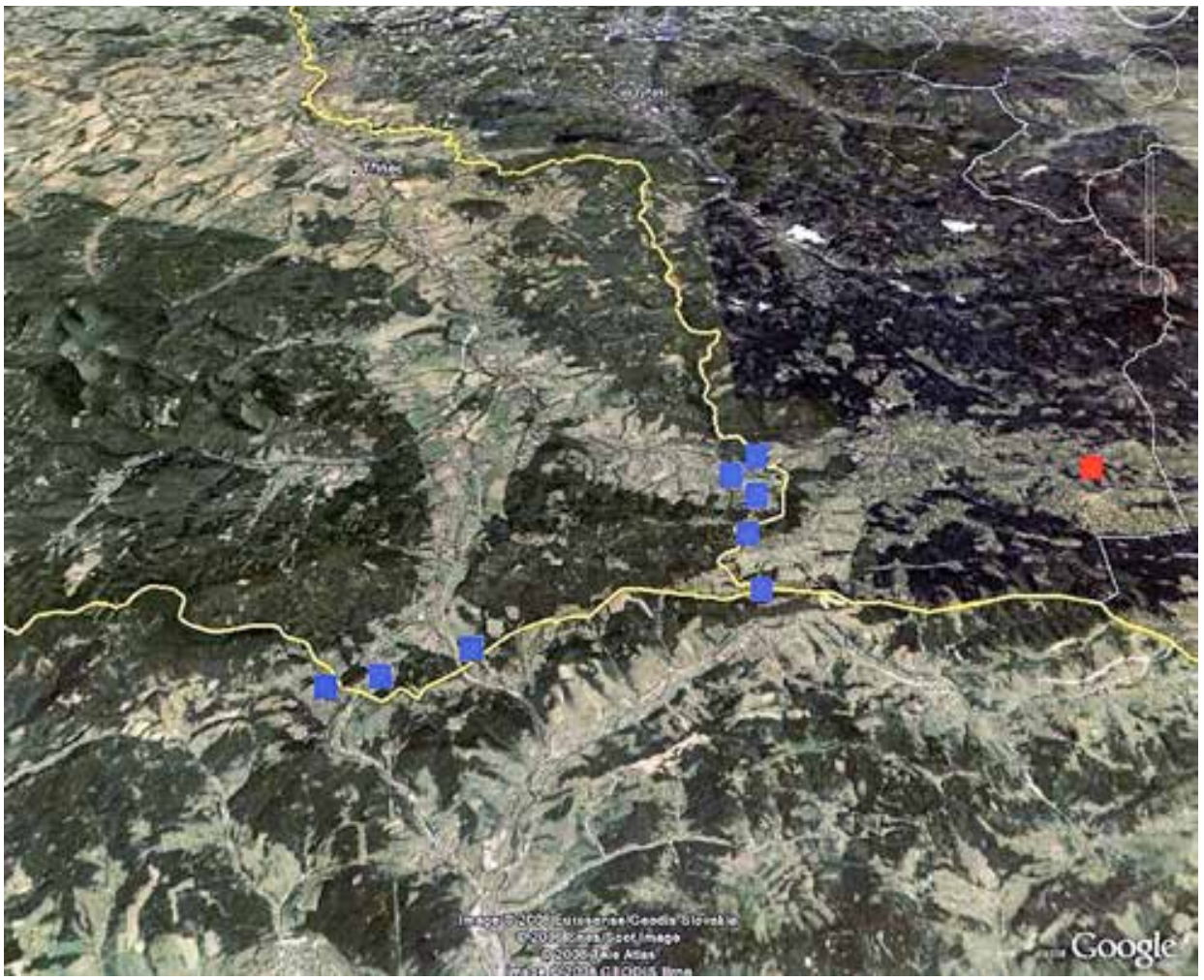

Obr. 13. Prostor slezsko-uherské hranice se zaznačením fortifikací, které byly modernizovány nebo nově vybudovány v poslední třetině 18. století na ochranu před útoky ze severozápadního směru. Červená - nedochovaná fortifikace, modrá - dochovaná fortifikace. Zdroj podkladové mapy Google Earth.

Abb. 13. Schlesisch-ungarisches Grenzland mit eingezeichneten Befestigungen, die im letzten Drittel zum Schutz vor Angriffen aus nordwestlicher Richtung modernisiert oder neu errichtet wurden. Rot - nicht erhalten gebliebene Befestigungen, blau - erhalten gebliebene Befestigungen. Quelle Basiskarten Google Earth.

bylo postřelovat údolí řeky Olše. Jednalo se o tři reduty a redan a o době jejich výstavby svědčí i soudobé označení „Laudonova reduta“ (Spyra-Chromik 2014, 534; obr. 13).

V naznačených dvou obdobích lze tedy zaznamenat rozdílnou typologii užitých polních opevnění, která souvisela se změnami taktického (větší využití dělostřelectva) i strategického charakteru (útoky na mnohakilometrové frontě několika samostatnými sbory).

Jablunkovské šance představují systém opevnění, jež svou dlouhodobou existencí pokrývající takřka dvě staletí umožňují sledovat typologický vývoj a změny polních opevnění. Z celkového počtu všech fortifikací zachycených ve zdejším prostoru na základě kartografických pramenů a terénního průzkumu, který činil 21 objektů (toto číslo však nemusí být konečné), se do dnešních dnů dochovaly relikty jedenácti z nich.

\section{Závěr}

Můžeme tedy sumarizovat, že důvodem pro vznik souvislé řady polních opevnění budovaných od hranic s Uhrami a Haličí až po území Čech se staly neúspěšné války o Slezsko s novým hlavním nepřítelem habsburské monarchie Pruským královstvím. V období vyčerpávajících válek probíhajících v krátkých intervalech po sobě nebyla příležitost realizovat obranu hraničních 
pohoří komplexním způsobem, přičemž jako nejvýhodnější se jevilo vybudovat v celém severním pohraničí soustavu polních opevnění.

Podle vyobrazení na prvním a druhém vojenském mapování, která přinášejí největší množství informací, probíhala výstavba polních opevnění ve dvou hlavních obdobích, a to během války o bavorské dědictví v letech 1778-1779 a na konci 80. let 18. století, v letech 1789-1790.

Rovněž z typologického hlediska došlo ke změně, jak je dobře patrné na prvcích obranného systému jablunkovského průsmyku. Nejpočetnější polní fortifikace 17. století představovaly většinou pěchotní uzavřená opevnění ve formě redut, hvězdicovitých šancí či šancí s bastiony, případně linie valu vyztužené redutami a redany (půlredutami). Svým účelem odpovídala tehdejšímu určení, kdy sloužila jako komunikační, strážní či předsunutá postavení hlavních opevnění, u kterých již můžeme pozorovat složitější tvarovou dispozici související s jejich významem a s dlouhodobou funkčností.

V období 18. století se typickými prvky stala otevřená dělostřelecká postavení ve formě redanů, lunet, biretů, barkánů či jejich různých terénních adaptací. Rovněž v lokalizaci můžeme vidět oproti předchozímu období jistý rozdíl. Fortifikace byly budovány na rozlehlých kopcovitých útvarech a výrazných strategických polohách, z nichž bylo dělostřelectvo schopno postřelovat široké okolí. Zároveň se rozšířil prostor obrany těchto fortifikací, kdy vznikala celá obranná pásma mnohem širšího rázu než v předchozí době. Jednalo se o reakci na vývoj vojenské strategie a taktiky druhé poloviny 18. století, která si koordinovaným postupem několika velkých armád vynutila hloubkové rozšíření obrany již na hranici země. Poznání typologie a lokalizace reliktů polních opevnění v terénu nám tedy usnadňuje chronologické určení těchto zajímavých antropogenních objektů, jež se stávají stále častěji předmětem odborného i laického zájmu a zároveň sílících snah o jejich využití v rámci turistického ruchu.

\section{Prameny a literatura}

BEDNÁR, P.-POLÁKOVÁ, Z.-VOJTEČEK, M., 2008: Stav a perspektívy archeologického výskumu pevnostného systému Jablunkovského priesmyku. In: „Šance - Valy Common Heritage“. Jablunkovské šance, 12-19. Žilina.

BEDNÁR, P. a kol., 2011: Bednár, P.-Krůl, M.-Poláková, Z.-Vojteček, M.-Bartík, M., Pevnostný systém Jablunkovského priesmyku. In: AVANS, 46-47. Nitra.

ČÍŽEK, J.-SLAVÍK, J., 1995: Polní opevnění za sedmileté války na Broumovsku. In: Fortifikace a obrana státu - Fortifications and defense of the state, 41-47. Praha.

- 2010: Zemní opevnění z 18. století ve východních Čechách. In: Polní opevnění od třicetileté války do roku 1945. Monumenta vivent (Macková, E., ed.), 37-44. Jaroměř-Josefov.

DILLER, O. F., 1955: Über die Technik von Befestigungsanlagen im Alterturm und im Mittelalter. Philo-Byzantinischen Akademie. Mitteilungen der Castellogischen Kommission 2. Stuttgart.

DUDÍK, B., 1879: Schweden in Böhmen und Mähren 1640-1650. Wien.

DUFFY, Ch., 1979: Siege Warfare. The Fortress in the Early Modern World 1494-1660. London - Henley.

- 1985: The Fortress in the Age of Vauban and Frederick the Great 1660-1789. Siege Warfare Volume II. London - Boston - Melbourne - Henley.

ĎURIŠOVÁ, M., 1995: Prieskum na Kysuciach. In: AVANS, 36-37. Nitra.

KAUfMANN, A., 2007: Gedenkbuch der Stadt Teschen. Teil II. (Buchholz-Johanek, I.-Spyra, J., edd.). Cieszyn.

KLAWITTER, W., 1941: Geschichte der schlesischen Festungen in vorpreusischer Zeit. Die Darstellungen und Quellen zur schlesischen Geschichte 39. Breslau.

KORBELÁŘOVÁ, I.-ŽÁČEK, R., 2005: Slezsko v I. vojenském (tzv. josefském) mapování. Opava.

KRŮL, M., 2010: Stav výzkumu novověkých opevnění slezsko-uhersko-polské hranice. In: Polní opevnění od trricetileté války do roku 1945. Monumenta vivent (Macková, E., ed.), 6-18. Jaroměř-Josefov.

- 2013: Fortyfikacje górskie Przełęczy Jabłonkowskiej. In: Twierdza Srebrnogórska IV. Wojna Siedmioletnia w Sudetach i nowożytne fortyfikacje górskie (Przerwa, T.-Podruczny, G., edd.), 59-74. Wrocław.

KRŮL, M.-NOVÁKOVÁ, P., 2005: Jablunkovské šance. Český Těšín.

KUCH-BREBURDA, M.-KUPKA, V., 2003: Pevnost Olomouc. Praha.

LISSEK, J.-STOKLASA, J., 1988: Zpráva. Zaměření fortifikace z tzv. 3. slezských válek. Opava. 
MATOUŠEK, V., 2006: Třebel. Obraz krajiny s bitvou. Praha.

- 2013: Budování polních opevnění v době třicetileté války. Zkušenosti z archeologických výzkumů na území Čech. In: Svorník 11/2013, 191-200. Praha.

MATOUŠEK, V.-HÁJEK, J.-KUBŮ, F.-MEDUNA, P., 1990: A complex investigation of a field fortification of the seven year's war (1756-1763) at the site of Nebesa by Aš (Asch). Excursus: H. Mevaldová: Folk tales on the hussars at Nebesa by Aš - Komplexní výzkum polního opevnění za sedmileté války v Nebesích u Aše. Pověsti o husarech v Nebesích u Aše, Studies in Post-Medieval Archaeology 1, 29-66.

MEDUNA, P., 1991: Morphology of field fortifications of the 17th-19th centuries. A contribution to surface research - Morfologie polních fortifikací 17.-19. století. Př́spěvek k povrchovému průzkumu, Studies in Post-Medieval Archaeology 1, 75-86.

NOTTNAGEL, Ch., 1659: Manuale Architecturae Militaris in Verlegung des Autoris. Wittenberg.

NEJMAN, M., 2010: Popis lokalit s polními fortifikacemi na severním bojišti války o bavorské dědictví zakreslených na mapových listech I. vojenského mapování. In: Polní opevnění od třicetileté války do roku 1945. Monumenta vivent (Macková, E., ed.), 45-59. Jaroměř-Josefov.

OESTA-KA, Karten umd Plansammlung: Österreichisches Staatsarchiv-Kriegsarchiv, fond Karten und Plansammlung, sign. K VII d $40 \mathrm{~F}$.

PARKER, G., 1996: The Military Revolution. Military innovation and the rise of the West 1500-1800. Cambridge.

KOLÁŘ, F., 2013: Opevnění Opavy v 17.-18. století. In: Opavské hradby (Kolář, F., ed.), 90-107. Opava - Ostrava.

PRCHAL, V., 2015: Společenstvo hrdinů. Válka a reprezentační strategie českomoravské aristokracie 1550-1750. Praha.

SMRŽ, Z.-MEDUNA, P.-BRU゚NA, V.-KŘIVÁNEK, R., 1999: Polní fortifikace z 18.-19. století u obce Poplze, okr. Litoměřice - Eine Feldfortifikation aus dem 18.-19. Jahrhundert bei der Gemeinde Poplze, Kreis Litoměřice, AR LI, 335-345.

SPYRA, J.-CHROMIK, G., edd., 2014: Malo invidiam quam misericordiam. Wybór pism i dokumentów dotyczących Leopolda Jana Szersznika. Bibliotheca Tessinensis VI. Series Polonica 3. Cieszyn.

ŠEDO, O., 1977: Opevnenie s bastiónmi v Svrčinovci. In: AVANS, 234-235. Nitra.

TSCHINK, C., 1791: Loudons Leben und Thaten. II. Theil. Wien.

UHLÍř, D., 2012: Epilog „českého“ Slezska v letech 1740-1763. In: Slezsko v dějinách českého státu II. 1490-1763 (Jirásek, Z., ed.), 365-398. Praha.

VOJTEČEK, M., 2016: Malé šance a valy v Čiernom. Príspevek k poznaniu pevnostného systému Jablunkovského priesmyku - Kleine Schantzen und Valy in Čierne. Ein Beitrag zum Festungssystem des Jablunkapasses, AH 41, 195-209.

WOHLMUTH, P., 2015: Bastionové pevnosti a vojenská revoluce. Praha.

ZAO, KrÚ: Zemský archiv v Opavě, fond Královský úřad Opava, inv. č. 604, fasc. 3.

ZAO, Vs Hradec: Zemský archiv v Opavě, fond Velkostatek Hradec, inv. č. 448, sign. VI 162, kart. 55.

\section{Zusammenfassung}

Der Schutz von nach Mähren und Ungarn führenden Gebirgspässen am Beispiel der Grätzer und Jablunkauer Schanzen

Der hier vorgelegte Beitrag versucht zu skizzieren, auf welche Art und Weise nach Mähren und Ungarn führende Gebirgspässe vor Einfällen aus Schlesien geschützt wurden. Am Beispiel von zwei relativ gut erhaltenen, Grätzer und Jablunkauer Schanzen genannten Feldbefestigungssystemen können Veränderungen in der Verteidigung von Gebirgsgegenden beobachtet werden, die auf taktische und strategische Entwicklungen reagierten und sich in der Typologie und der Ortswahl der Befestigungen widerspiegelten. Die Jablunkauer Schanzen als zum Schutz der südschlesischen Grenze vor Einfällen aus Ungarn errichtetes Feldbefestigungssystem begannen sich bereits in der ersten Hälfte des 16. Jahrhunderts als Reaktion auf die Expansion des Osmanischen Reiches in den mitteleuropäischen Raum zu konstituieren. Ihre - wenn auch bereits geringere - Bedeutung hat die Befestigungsanlage auch im 18. Jahrhundert noch beibehalten, als sie auf die Verteidigung vor dem neuen Feind der Habsburger Monarchie - dem Königreich Preußen - ausgerichtet war. Gegen den gleichen Feind begann man in der zweiten Hälfte des 18. 
Jahrhunderts auch die Zugangskorridore in den südlichen Teilen des österreichischen Schlesiens zu befestigen, um ein Vorrücken nach Mähren zu verhindern. Zu den hier am besten erhaltenen Befestigungen zählen die in der Umgebung von Hradec nad Moravicí (Grätz) errichteten Grätzer Schanzen. Die aufzehrenden, in kurzen Intervallen nacheinander erfolgenden Kriege boten nicht viel Gelegenheit, eine Verteidigung von Gebirgsgrenzlandgebieten komplex zu realisieren, wobei sich als die geeignetste Lösung erwies, im gesamten nördlichen Grenzland ein Feldbefestigungssystem aufzubauen. Gemäß den Darstellungen auf der ersten und zweiten militärischen Kartierung, welche die größte Fülle an Informationen liefern, erfolgte der Aufbau der Feldbefestigungen in zwei Hauptperioden, und zwar während des Bayerischen Erbfolgekrieges in den Jahren 1778-1779 und Ende der achtziger Jahre des 18. Jahrhunderts in den Jahren 1789-1790. Auch in typologischer Hinsicht kam es zu einer Änderung, wie an den Elementen des Verteidigungssystems des Jablunkauer Passes gut zu erkennen ist. Die meisten Feldbefestigungen stellten im 17. Jahrhundert infanteristisch geschlossene Befestigungen dar, welche die Form von Redouten, Sternschanzen oder Schanzen mit Bastionen, gegebenenfalls eine mit Redouten und Redans (Halbredouten) verstärkte Walllinie hatten. Ihrem Zweck nach entsprachen sie der damaligen Bestimmung, als sie als Wege-, Wach- oder vorgezogene Stellung der Hauptbefestigungen dienten, bei denen man bereits eine kompliziertere Anlage der Formen beobachten kann, die mit ihrer Bedeutung und langfristigen Funktionsfähigkeit zusammenhing.

Für die Zeit des 18. Jahrhunderts wurden offene Geschützstellungen in Form von Redans, Lünetten, Biretts, Barkans oder deren verschiedenen Geländeanpassungen zu den typischen Elementen. Auch in der Ortswahl können wir gegenüber dem vorhergehenden Zeitraum einen gewissen Unterschied feststellen. Die Befestigungen wurden auf ausgedehnten hügeligen Gebilden und in markanten strategischen Lagen errichtet, von wo aus die Artillerie die breite Umgebung unter Beschuss nehmen konnte. Gleichzeitig wurde der Verteidigungsraum dieser Befestigungen größer, indem ganze Verteidigungszonen viel breiterer Art als in früherer Zeit entstanden. Dabei handelte es sich um eine Reaktion auf die Entwicklung der Militärstrategie und -taktik der zweiten Hälfte des 18. Jahrhunderts, die mit ihrem koordinierten Vorrücken mehrerer großer Heere bereits an der Landesgrenze eine in die Tiefe gehende Vergrößerung der Verteidigung erforderlich machte. Das Erkennen der Typologie und der Ortswahl von Feldbefestigungsrelikten im Gelände erleichtert uns demnach eine chronologische Bestimmung dieser interessanten anthropogenen Objekte.

Mgr. Martin Krůl, Muzeum Těšínska, p. o., Masarykovy sady 103/19, 73701 Český Těšín, Česká republika, Martin.Krul@seznam.cz 
